\title{
A scientific note on honey bee foraging activity and airborne pollen flow*
}

\author{
Bernardo SABUgosA-MAdEIRA $^{\mathrm{a}, \mathrm{b}}$, Ilda ABREU ${ }^{\mathrm{b}}$, Helena RIBEIRo $^{\mathrm{a}, \mathrm{b}}$, Alexandra GoMES ${ }^{\mathrm{a}}$, Mário CUNHA ${ }^{\mathrm{a}}$ \\ a Secção Autónoma de Ciências Agrárias, FC-UP, and CECA-ICETA, Rua Padre Armando Quintas, 4485 - 661 Vairão, \\ Portugal

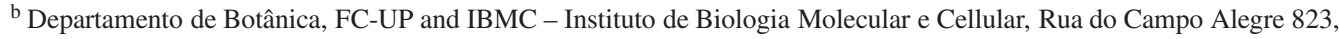 \\ 4150 - 180 Porto, Portugal
}

Received 27 October 2005 - Revised 13 March 2006 - Accepted 17 March 2006

Apis mellifera / foraging / airborne pollen

Several factors affect a honey bee colony's collection of pollen. Most studies on this topic have focused on the colony's response to stimuli located within the nest, principally the amount of brood and stored pollen (Hrassnigg and Crailsheim, 1998; Dreller et al., 1999; Fewell and Bertram, 1999; Rotjan et al., 2002; Vaughan and Calderone, 2002). One area that has not received adequate attention is the relationship between pollen collection and its availability in the natural environment.

During the last few years, aerobiology studies demonstrated a link between airborne pollen concentration and the number of flowers in the area surrounding the sampler (Reddi and Reddi, 1985; Besselat and Cour, 1990; Cunha et al., 2003; Thibaudon and Lachasse, 2005). The aim of our work was to compare the total airborne pollen flow, collected with airborne samplers, with the total amount of pollen collected by honey bee colonies.

Sampling was done in the northwest littoral of Portugal, in two rural areas, Cesar $\left(40^{\circ} 55^{\prime} \mathrm{N}\right.$, $8^{\circ} 25^{\prime} \mathrm{W}, 300 \mathrm{~m}$ altitude) and Vairão $\left(41^{\circ} 20^{\prime} \mathrm{N}\right.$, $\left.8^{\circ} 40^{\prime} \mathrm{W}, 100 \mathrm{~m}\right)$, and one urban area, Porto $\left(41^{\circ} 11^{\prime} \mathrm{N}, 8^{\circ} 39^{\prime} \mathrm{W}, 50 \mathrm{~m}\right)$. Airborne pollen flow and bee-collected pollen were studied in 2003 and 2004 at Cesar and Vairão, and in 2004 at Porto. At Cesar and Vairão, the airborne pollen content was sampled using two "Cour-type" samplers (Cour, 1974) placed at $12 \mathrm{~m}$ and $7 \mathrm{~m}$, respectively, above ground level. The pollen was trapped in filters which were changed weekly. After acetolysis (Erdtman, 1960),

Corresponding author: I. Abreu, inoronha@ibmc.up.pt

* Manuscript editor: Jacqueline Pierre identification of pollen grains was made. Pollen counts were converted to correspond to airborne pollen flow (APF) per square meter per day. At Porto, a Burkard 7-day volumetric trap with a flow rate of 10 litres per minute was used at $12 \mathrm{~m}$ above the ground. In this case, pollen counts were converted to correspond to airborne pollen concentration (APC) per cubic meter of air sampled per day.

Pollen collection in honey bee colonies (one colony per location) was carried out with an upperentrance pollen trap installed on the top of each hive (Lavie and Fresnaye, 1963). Pollen was collected weekly from traps at Cesar and Vairão and twice weekly at Porto. The collected pollen represented about $14 \%$ of incoming pollen.

The relationship between total airborne pollen (APF in Cesar and Vairão; APC in Porto) and the total weight of pollen collected in pollen traps was evaluated separately for each location and year using the Pearson correlation coefficient (analyses based on monthly data). Significant correlations ranging from $r=0.86$ to $r=0.95$ were found in each case (Fig. 1). Further research on the relationship between environmental food availability and harvesting behaviour should be conducted. Special attention should be directed to the taxonomic overlaps between airborne and honey bee pollen.

\section{ACKNOWLEDGEMENTS}

First author is supported by Fundação para a Ciência e Tecnologia (BD/7049). The authors also thank Eng ${ }^{\circ}$ Henrique Arteiro, Dr ${ }^{\mathrm{a}}$ Isabel Paradela and Luísa Damas for all technical support and Direcção Regional de Agricultura de Entre Douro e 


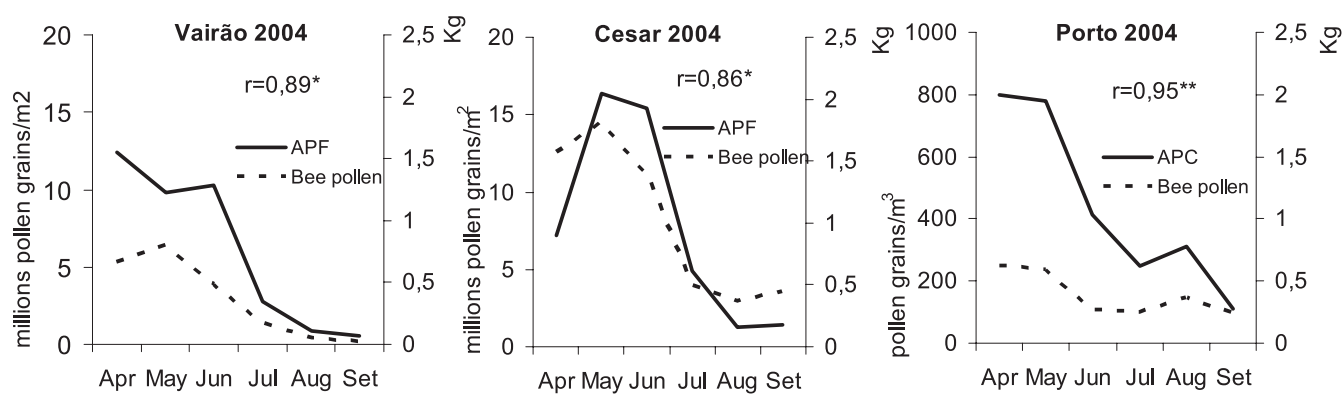

Figure 1. Relationship between the weight of pollen collected in pollen traps and APF or APC in the studied places and years. $r$ - Pearson coefficient correlation between honey bee collected pollen (monthly data) and APF or APC; $n=6$. $*$ Correlation significant at 0.05 level. ** Correlation significant at 0.01 level.

Minho for the meteorological data and conditions provided. The constructive comments of the referees and the careful reading of the manuscript by $\mathrm{Dr}^{\mathrm{a}}$ Isabel Rocha are gratefully acknowledged.

\section{Note scientifique sur l'activité de butinage des abeilles domestiques et du flux pollinique atmo- sphérique.}

\section{Zusammenfassung - Eine wissenschaftliche No- tiz zur Sammelaktivität von Honigbienen und zum Pollenflug.}

\section{REFERENCES}

Besselat B., Cour P. (1990) La prévision de la production viticole à l'aide de la technique de dosage pollinique de l'atmosphère, Bull. Off. Int. Vin 63, 715-716.

Cour P. (1974) Nouvelles techniques de détection des flux et des retombées polliniques : étude de la sédimentation des pollens et des spores à la surface du sol, Pollen et Spores $16,103-141$.

Cunha M., Abreu I., Pinto P., Castro R. (2003) Airborne pollen samples for early-Season estimates of wine production in a mediterranean climate of northern Portugal, Am. J. Enol. Viticult. 54, 189-194.
Dreller C., Page R., Fondrk M. (1999) Regulation of pollen foraging in honeybee colonies: effects of young brood, stored pollen, and empty space, Behav. Ecol. Sociobiol. $45,227-233$.

Erdtman G. (1960) The acetolysis method. A revised description, Sven. Bot. Tidskr. 39, 561-564.

Fewell J., Bertram S. (1999) Division of labor in a dynamic environment: response by honeybees (Apis mellifera) to graded changes in colony pollen stores, Behav. Ecol. Sociobiol. 46, 171-179.

Hrassnigg N., Crailsheim K. (1998) The influence of brood on the pollen consumption of worker bees (Apis mellifera L.), J. Insect Physiol. 44, 393-404.

Lavie P., Fresnaye J. (1963) Étude expérimentale de la trappe à pollen en position supérieure, Ann. Abeille 6, 277-301.

Reddi C., Reddi N. (1985) Relation of pollen release to pollen concentration in air, Grana 24, 109-113.

Rotjan R., Calderone N., Seeley T. (2002) How a honey bee colony mustered additional labor for the task of pollen foraging, Apidologie 33, 367.

Thibaudon M., Lachasse C. (2005) Phénologie : intérêt et méthodes en aérobiologie, Rev. Fr. Allergol. Immunol. Clin. 45, 194-199.

Vaughan D., Calderone N. (2002) Assessment of pollen stores by foragers in colonies of the honey bee, Apis mellifera L., Insectes Soc. 49, 23-27. 